\title{
Climate trends and variability in Ecuador (1966-2011)
}

\author{
Enrique Morán-Tejeda, ${ }^{\mathrm{a}, \mathrm{b} *}$ Juan Bazo,${ }^{\mathrm{c}}$ Juan I. López-Moreno, ${ }^{\mathrm{a}}$ Enric Aguilar, ${ }^{\mathrm{d}}$ \\ César Azorín-Molina, ${ }^{a}$ Arturo Sanchez-Lorenzo, ${ }^{a}$ Rodney Martínez, ${ }^{\mathrm{e}}$ Juan J. Nieto, \\ Raúl Mejía, ${ }^{\mathrm{f}}$ Natalia Martín-Hernández ${ }^{\mathrm{a}}$ and Sergio M. Vicente-Serrano ${ }^{\mathrm{a}}$ \\ a Pyrenean Institute of Ecology-CSIC, Geoenvironmental Processes and Global Change, Zaragoza, Spain \\ ${ }^{\mathrm{b}}$ Department of Geography, University of Balearic Islands, Palma de Mallorca, Spain \\ c Servicio Nacional de Meteorología e Hidrología de Perú, Climatology, Climate Change and Climate Modeling, Lima, Perú \\ ${ }^{\mathrm{d}}$ Rovira $i$ Virgili University, Center for Climate Change, Tarragona, Spain \\ e Centro Internacional para la Investigación del Fenómeno de El Niño (CIIFEN), Guayaquil, Ecuador \\ ${ }^{\mathrm{f}}$ Instituto Nacional de Meteorología e Hidrología (INAMHI), Quito, Ecuador
}

\begin{abstract}
This study detects climate trends and variability from precipitation and temperature observations in Ecuador and assesses their links to the El Niño Southern Oscillation (ENSO) for the period 1966-2011, using the El Niño 1+2 and El Niño 3.4 indices. Excluding the Amazonian region (for which there is a lack of data), two main regions were distinguishable in terms of variability and trends among climate variables, especially for precipitation. In general, there was no trend in precipitation for the coastal region, and a very close relationship between the magnitude and seasonal distribution of precipitation and the El Niño 1+2 variability was found. In contrast, for the mountainous region (the Andes), there was an increase of precipitation during the study period, and a signal of El Niño 3.4 influence was detected. Temperatures were spatially homogeneous and showed an intense warming trend, except for maximum temperatures in the coastal region. The El Niño $1+2$ influence on temperature was large from January to July. The results provide evidence of the close control exerted by the ENSO, especially in the coast of Ecuador, as well as for the occurrence of significant warming across the country independent of the ENSO phenomenon.
\end{abstract}

KEY WORDS precipitation; temperature; ENSO; ecuador; trends; variability

Received 26 January 2015; Revised 10 November 2015; Accepted 12 November 2015

\section{Introduction}

The tropical Andean region has been recognized as an area of high vulnerability to climate change and related hydroclimatic hazards (IPCC-SREX, 2012; WFP, 2014). The climate of the region is affected by various and contrasting topographic and atmospheric mechanisms, leading to complex phenomena and different degrees of variability, which complicates assessment of possible climate change effects. The region is affected by the displacement of the Intertropical Convergence Zone (ITCZ) but is also subject to trade winds, the influence of Hadley and Walker circulations cells and moisture advection from the Amazonian basin. Moreover, the Andean mountain chain induces topographic uplift of air masses, thus substantially modulating the precipitation regime (Poveda et al., 2006; Herzog et al., 2011). One of the major concerns for understanding climate variability and extremes is related to the coupled atmospheric-oceanic modes. The El Niño Southern Oscillation (ENSO) is the main pattern of climate variability in the Pacific Ocean region and the tropical Andes (Poveda et al., 2006) and is characterized

\footnotetext{
* Correspondence to: E. Morán-Tejeda, Department of Geography, University of the Balearic Islands, Cra. de Valldemossa, Km 7.5 - 07122, Palma de Mallorca, Spain. E-mail: e.moran@uib.eu; enriquemoran@ gmail.com
}

by periodic fluctuations in the sea surface temperature (SST) and related anomalies in surface air pressure over the Pacific Ocean and spatial propagation worldwide in the mid troposphere (e.g. Vicente-Serrano et al., 2011). This phenomenon induces inter-annual climate variability, and during its warm (El Niño) and cold (La Niña) phases, extreme events including floods and droughts cause disasters, affecting millions of people in the region (Grimm et al., 2000; Larkin and Harrison, 2002). Another important driver of variability is the Pacific Decadal Oscillation (PDO), a pattern exhibited by the surface waters of the Pacific Ocean north of $20^{\circ} \mathrm{N}$, which shifts between warm and cool phases at inter-decadal timescales (Mantua et al., 1997; Hare et al., 1999). Despite this signal being most evident in the North Pacific, there is increasing evidence of its influence in South America (Mantua and Hare, 2002).

Climate change is thought to increase the frequency and magnitude of hydroclimatic hazards (Stocker et al., 2013) and other climate-related processes including glacier retreat and water availability in the region (Bradley et al., 2006; Vuille et al., 2008; López-Moreno et al., 2014). Furthermore, the economies in large areas of the countries in the region are based on traditional activities of local communities, which largely depend on climate variability (particularly as it affects water availability and the temperature conditions). 
The issues noted above highlight the need for a comprehensive understanding of climate variability and change processes in the Andean countries, particularly in relation to prevention of climate disasters and the negative impacts of climate change on the environment and societies (Mora and Willems, 2012). Evidence of this includes the growing scientific literature on climate variability and trends on national and regional levels in South America in general and for the tropical Andes and the Amazonian basin in particular (see examples in Poveda et al., 2006 and Garreaud, 2009). On the transnational level, Espinoza-Villar et al. (2009) reported a significant decrease in precipitation since the 1980s in the Amazonian basin and precipitation variability strongly influenced by the ENSO. A broader study by Haylock et al. (2006) showed increasing precipitation in Ecuador and northern Peru and contrasting trends in the southern countries of the continent. Although the occurrence of global warming has been accepted during recent decades, the cooling of the Chilean coastal region reported by Falvey and Garreaud (2009) demonstrates the need for local high-resolution studies to better characterize climate trends and variability. This has not been possible in some countries mainly due to the absence of long-term data and in other cases, due to the lack of adequate quality control and homogenization of the available data sets. During the last few years, significant progress has been made, and quality data is now available from long-term stations in South America. This has resulted in a number of reports addressing climate trends and variability for a number of countries in the region (e.g. Carmona and Poveda, 2014 for Colombia; Casimiro et al., 2013 for Perú; Seiler et al., 2013 for Bolivia; and Skansi et al., 2013 for the entire South America).

The study of climate trends and variability in Ecuador is particularly interesting because of its exposure to the Pacific Ocean and the direct effects of the ENSO. In relation to the latter, the presence of the Andes barrier is likely to strongly modify the ENSO signal (Vuille et al., 2000). Various studies have considered precipitation in Ecuador (Rossel et al., 1999; Bendix and Bendix, 2006; Buytaert et al., 2006) or have focused on precipitation and temperature in small areas of the country (Mora and Willems, 2012). In general, a strong connection between the ENSO and precipitation in Ecuador has been found, but none of the previous studies analysed stations throughout the entire country. Moreover, the various studies focusing on precipitation trends did not show agreement on the sign of the trends, these being strongly dependent on the stations and the time period analysed. Thus, a study of trends and variability in precipitation and temperature, based on up-to-date data for the entire country, has been lacking. With the availability of climate data recently recovered and digitalized by the Ecuador National Institute for Meteorology and Hydrology (Instituto Nacional de Meteorología e Hidrología - INAMHI), this type of study is now possible for the entire country, except in large areas of the Amazonas sector where the observation station network is extremely sparse.
The present study aims at investigating the main spatio-temporal variability of precipitation and temperature in Ecuador along with their long-term trends, based on a principal component analysis (PCA) and a multi-period trend analysis. Moreover, the spatio-temporal effects of the ENSO phenomenon on the country based on correlations between the climate variables and the El Niño 1+2 and the El Niño 3.4 indices are evaluated.

\section{Study area}

Ecuador is located in the South American continent between the Pacific Ocean and the Amazon basin, occupying an area of $256370 \mathrm{~km}^{2}$ to the north and (mostly) south of the Equator (Figure 1). The Andean mountain chain crosses the country in a north-south direction and constitutes a substantial topographic barrier, with large areas exceeding $4000 \mathrm{~m}$ asl and the highest summits reaching approximately $6300 \mathrm{~m}$ asl. The average precipitation along the coast and in the lowlands for the period 1965-2011 was approximately $1600 \mathrm{~mm}$ year $^{-1}$, whereas at the stations in the Andes, the annual precipitation does not reach $900 \mathrm{~mm}$. The sole station located in the Amazonian basin registered an average precipitation value of $4600 \mathrm{~mm}^{-1}$ during the study period. The meridional ITCZ displacement and SST fluctuations determine the precipitation regimes. The rainy season is associated with the ITCZ and the equatorial front location in its southernmost position where warm moist air masses originanting from the northwest cover the coastal region, bringing significant rainfall and raising air temperatures. Inversely, the northernmost ITCZ displacement and the equatorial front result in the presence of cooler and dryer air masses descending from upwelling regions in the southwest, influencing the dry season (Rossel and Cadier, 2009). Consequently, precipitation is not evenly distributed during the year, with $80 \%$ of the annual rainfall occurring from December to May (the 'wet season'). No distinct seasons can be distinguished for temperature, which grades from the coast (annual average $26^{\circ} \mathrm{C}$ ) to the mountains $\left(12^{\circ} \mathrm{C}\right.$ ) (Figure 1, right bottom plot).

\section{Data and methods}

\subsection{Climate data}

Data on daily precipitation and maximum and minimum temperatures were obtained from INHAMI and were pre-processed at the International Research Centre on EL Niño (Centro Internacional para la Investigación del Fenómeno de El Niño; CIIFEN) within the framework of the project Climate Change and Biodiversity Information for the Enhancement of Conservation and Adaptation Policies in the Tropical Andes Region. Daily climate series from 50 stations in Ecuador were quality controlled using the specifically designed HOMER software, which identified and removed gross measurement errors and identified and corrected transcription and data formatting problems (Aguilar et al., 2003). The present study 

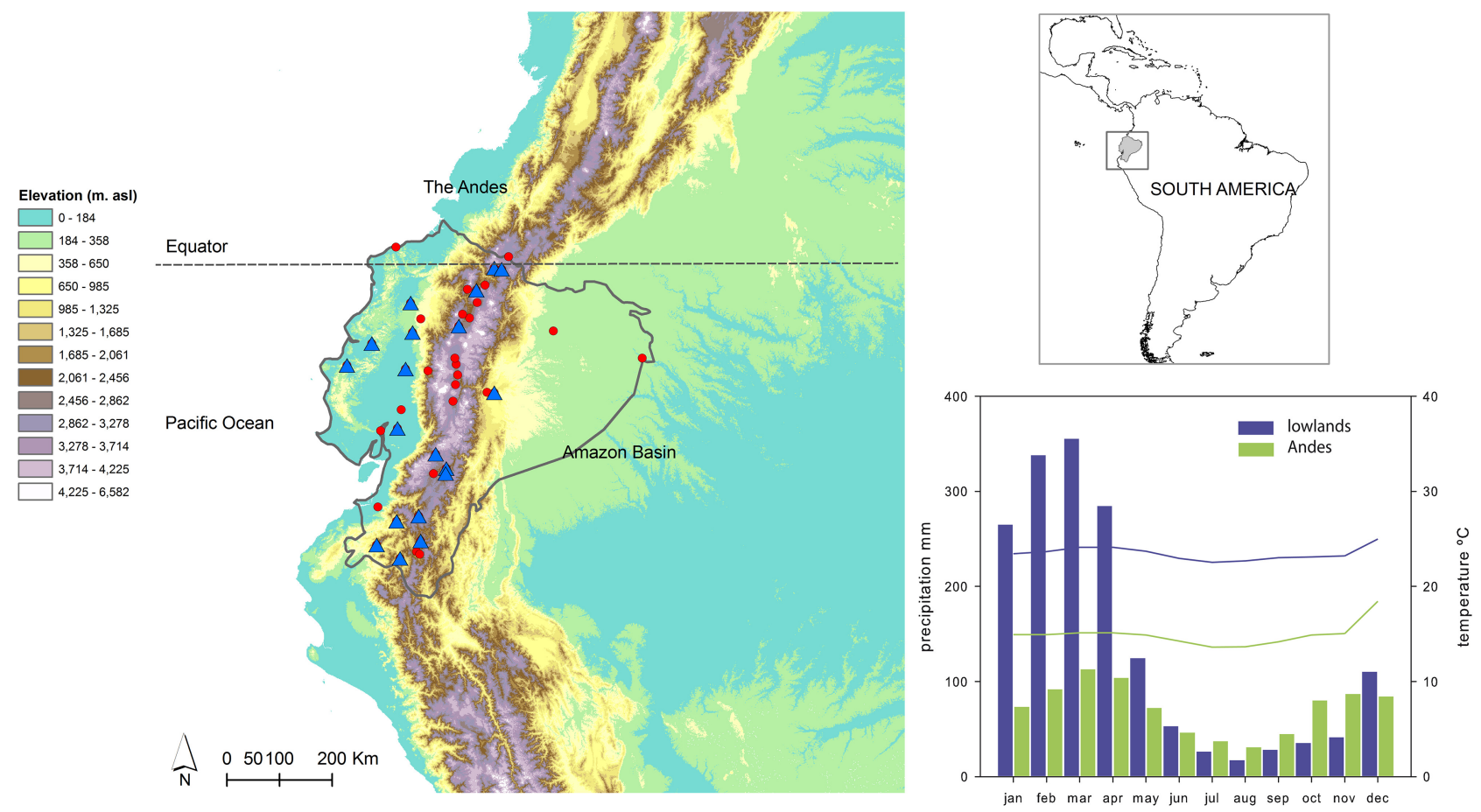

Figure 1. Location of Ecuador showing those meteorological stations that were included in the analysis (triangles) and those that were discarded (circles). The right plot shows the mean precipitation (bars) and temperature (lines) monthly regimes in the coastal lowlands and in the Andean mountain stations.

identified 19 stations with sufficient data coverage for the period $1966-2011$ (less than $15 \%$ of daily missing values) and from these data, computed monthly average values for daily maximum $\left(T_{\max }\right)$ and minimum $\left(T_{\min }\right)$ air temperature and monthly accumulations of daily precipitation, only when all daily records within a month were present. Inhomogeneities and missing values in monthly data were checked and reconstructed using HOMER software (see details in Mestre et al., 2013), which contains, as a preliminary detection tool, the pairwise algorithm and the two-factor analysis of variance (ANOVA) model for correction described by Caussinus and Mestre (2004). A conservative homogenization procedure combining the automatic application of the algorithm with a supervised check was performed to discard from correction those break points that could be caused by climate processes. This resulted in corrections involving 11 break points among 5 precipitation stations and 36 break points among 12 temperature stations. These break points were considered to be independent of the variability or trends intrinsic to the climate series. The spatial coverage of the stations was reasonable except for the Amazonian region (east), where data was scarce and not suitable for climatological analysis (Figure 1).

The ENSO is a complex ocean-atmospheric phenomenon of variable extent and intensity and contrasted impacts. Proof of this is the number of indices used to characterize it [Oceanic Niño Index (ONI), Southern Oscillation Index (SOI) or the indices computed for each ENSO region, i.e. El Niño 1+2, El Niño 3, El Niño 4, El Niño 3.4] or even the existence of various ENSO modes
(El Niño and El Niño Modoki, e.g.: Ashok et al., 2007; Takahashi et al., 2011). It is known that the ENSO has contrasted impacts over the coast and inlands of tropical South America. On the coast, strong convection due to warmer SST during El Niño enhances precipitation with respect to neutral ENSO conditions (Rossel and Cadier, 2009). On the contrary, convection over the central Pacific during El Niño affects Walker circulation in the upper troposphere, and intense subsidence occurs over Brazil, leading to drought conditions over the inlands of the continent (Poveda et al., 2006). In order to reflect these two contrasted impacts, two ENSO indices were selected, El Niño $1+2$ and El Niño 3.4 (http://www.cpc.ncep.noaa.gov/), that represent anomalies in the coastal region and central Pacific SST, respectively.

El Niño (warm) and La Niña (cold) events were identified on the basis of thresholds of the smoothed (3-month moving average) series of El Niño 1+2 and El Niño 3.4. For El Niño 1+2, the ICEN index (Coastal El Niño Index, Índice Costero El Niño, ENFEN, 2012) was used, which considers El Niño events as those months with a value $>1$ and La Niña events as those months with a value $<-1$. Months with values within that range were considered to be 'neutral events'. For El Niño 3.4, the ONI (CPC-NOAA, 2006) was used, for which El Niño months are those with a value $>0.5$ and La Niña months those with a value $<-0.5$. El Niño/La Niña years defined from the ICEN and ONI indices do not necessarily coincide, indicating the complex spatio-temporal variability of the ENSO. Figure 2 shows the series of the two respective indices, indicating when El Niño, La Niña and neutral months occurred. 


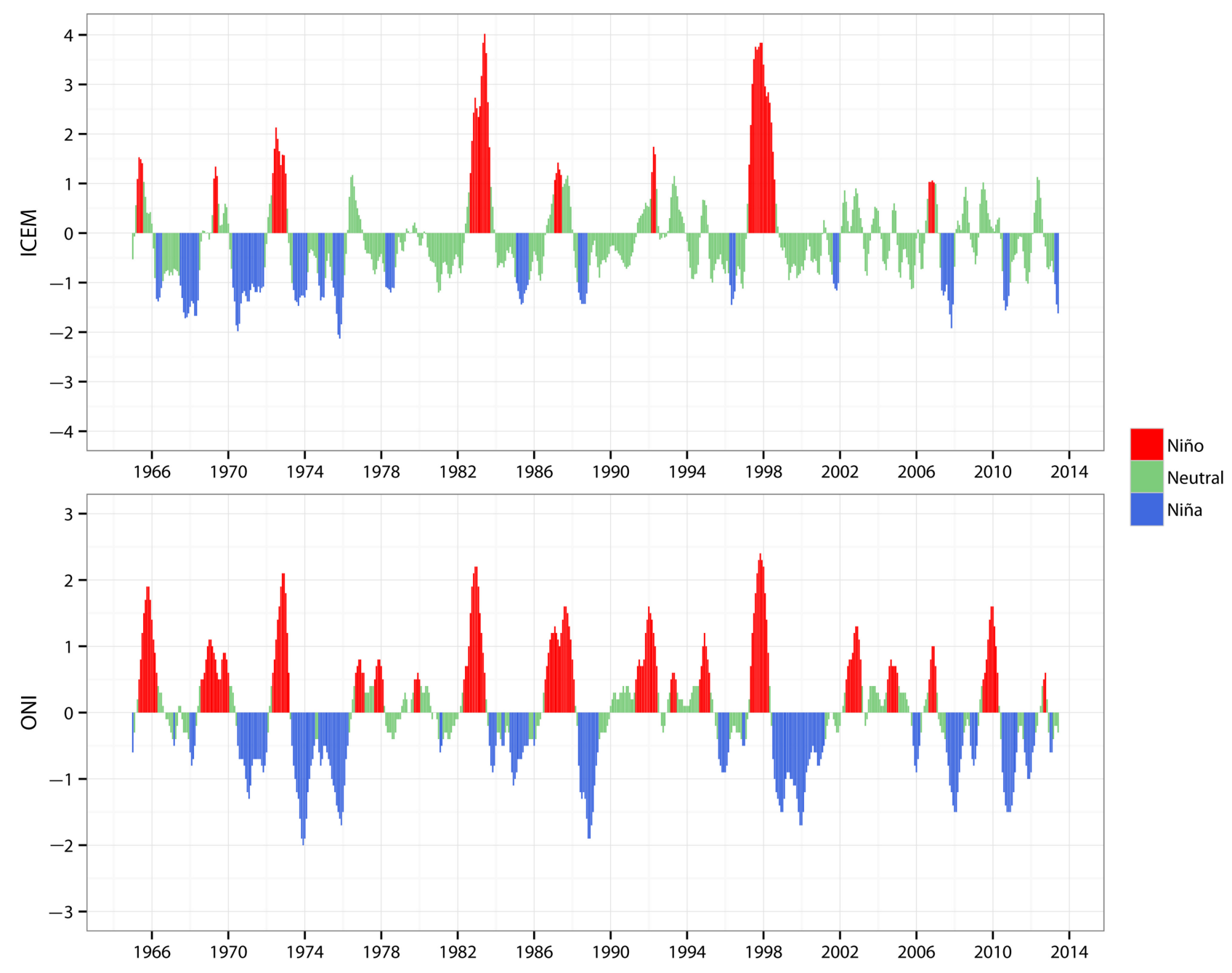

Figure 2. Temporal series of ICEAM and ONI indices, with indication of El Niño, and La Niña events.

\subsection{Exploratory analysis}

Prior to assessing trends in the data series, an exploratory analysis was performed to detect possible redundancies and search for common patterns in the evolution of climate variables. This was performed using a PCA in S mode (with the climate series from the various stations as input variables and the various monthly values as the cases). This technique enables the detection of autocorrelation in the sample of variables (through a correlation matrix) and constructs new orthogonal (non-correlated) variables, termed principal components (PCs), which are lineal combinations of the original variables and capture most of the original variance in the data (Jolliffe, 2005). To facilitate the interpretation of the resulting PCs (i.e. the basic modes of variability in precipitation and temperature), a varimax rotation of the axis was performed, which enabled their approximation to the original variables to be maximized (Richman, 1986).

\subsection{Trend and correlation analyses}

Following completion of the exploratory analysis, trends in the climate series were computed and their statistical significance was assessed using the Mann-Kendall test. This test has been broadly used in climatological studies for detecting trends because of its non-parametric nature, which prevents outliers or non-normal distributions from affecting the probability of rejecting the null hypothesis (no trend). Prior to applying the trend test, the trend-free pre-whitening procedure (Yue et al., 2002) for removing the autocorrelation (AR1) was performed, when present in the series. This entire procedure was performed using the 'zyp' package developed by Bronaugh and Werner (2013) for the R statistical computing environment. The length of the climate series enabled trends for different sub-periods to be computed and so enabled the detection of points at which a change in the sign of the trend occurred or years where the trend weakened or became stronger. This was achieved by calculating trends for all possible combinations of periods of a minimum of 30 years in length, from the beginning of the study period. The results were trend matrices (so-called heat maps), which are easy to interpret and facilitate clear visual representations of the information. Trend analyses for the annual and seasonal means (temperature) and totals (precipitation) were performed based on the long-term precipitation regime (Figure 1) (as there are no 

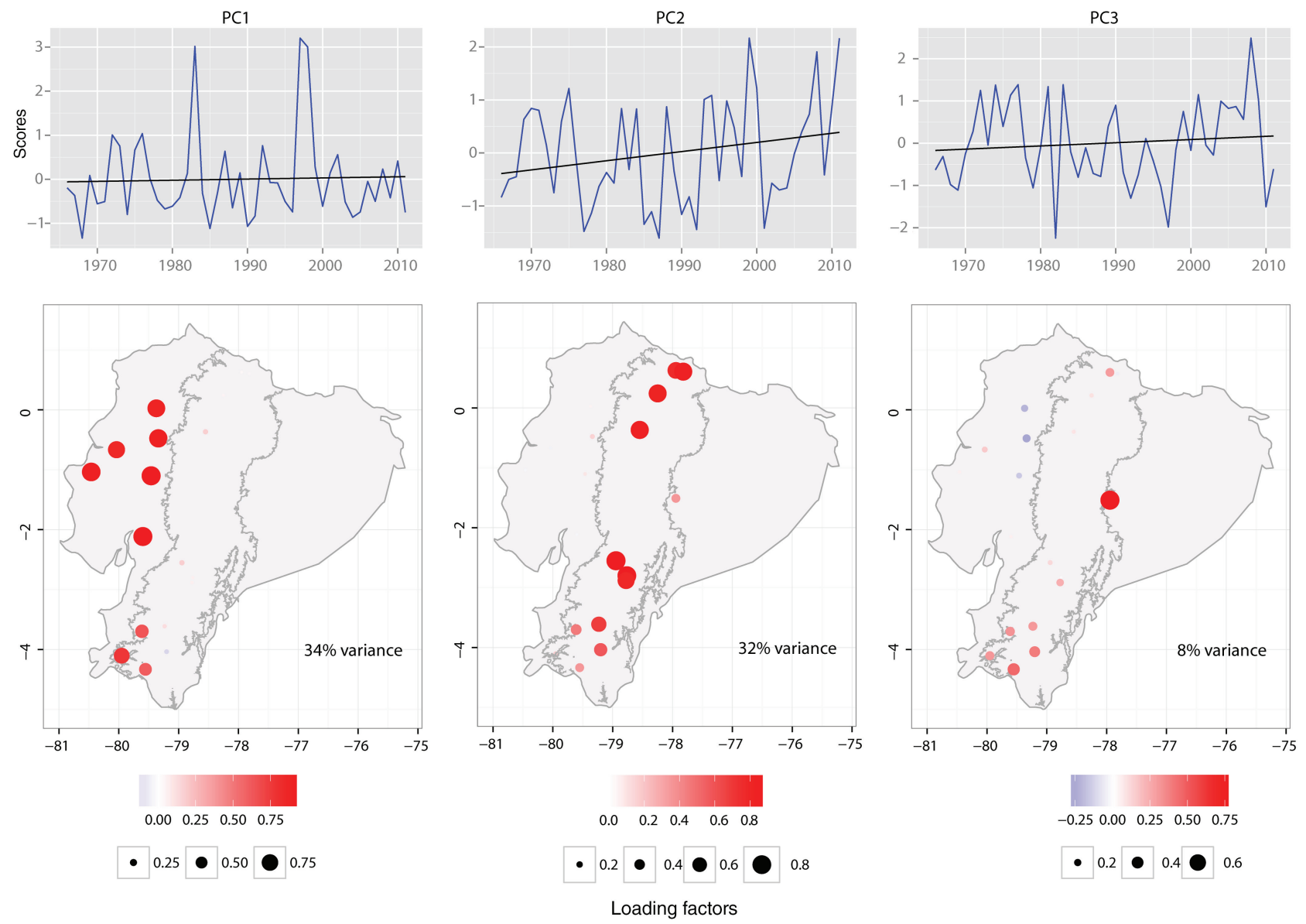

Figure 3. Spatial and temporal variability of precipitation. Upper panels show the factorial scores for the PCs obtained. Lower panels show the loading factors of precipitation series with each PC. The scale indicates the intensity and sign, and the point size indicates the absolute values for the loading factors. Spatial extent of the Andean chain is depicted by a contour line at $1000 \mathrm{~m}$ asl.

conventional seasons in the regions near the Equator). The 'wet season' was defined as December-May and the 'dry season' as June-November, and trend analyses for total precipitation and averaged temperature for these seasons were performed.

To characterize the influence of the ENSO on the climate of Ecuador, correlation tests (Pearson's correlation) were performed between the ENSO indices and the climate variables on the monthly level. These correlations were computed on the detrended series of precipitation, $T_{\max }$ and $T_{\min }$; this was done to remove noise in the observed trends of the climate variables during the study period.

\section{Results}

\subsection{Precipitation}

Figure 3 shows the main variability in precipitation across Ecuador. Three PCs explained most of the variance in the original precipitation series, although the third PC represented only one station (the sole station located in the Amazonian basin), and thus it was discarded from further analyses. In Figure 3, the loading factors for the PCs show a clear spatial structure. PC1 explained $34 \%$ of the variance and represents the stations located in the lowlands near the Pacific Ocean coast. The temporal evolution of precipitation at these stations is summarized by the factor scores for PC1 (left upper panel). This shows a stationary evolution of precipitation (no trend) with two peaks (in the years 1983 and 1997, respectively), which correspond to the most extreme El Niño events when the maximum ocean temperatures were recorded (discussed below). In contrast, PC2 showed an increasing trend in precipitation associated with stations located in the Andean region. The 1965-2011 trend analysis was conducted for all stations, but a more detailed analysis (30-year time slice running trends) was performed only for those stations that were more representative of each PC (the station most correlated with each extracted PC). This was performed for the total annual precipitation and also for the wet and dry seasons. Table 1 shows the percentage of stations showing positive and negative precipitation trends during the study period. For annual precipitation, there was a prevalence of positive coefficients $(78 \%)$ but no significant trends at the $95 \%$ confidence level. This proportion was also observed for the wet season (with only two stations showing significant positive trends), but for the dry season, negative coefficients prevailed (although they were mostly non-significant). We sorted the stations by PC and confirmed that stations represented by PC1 showed no 
Table 1. Percentage of stations showing negative and positive tau coefficients and significant trends in precipitation.

\begin{tabular}{|c|c|c|c|c|c|c|c|}
\hline & \multirow[t]{2}{*}{ Tau coeff. } & \multicolumn{2}{|c|}{ Annual } & \multicolumn{2}{|c|}{ Wet season } & \multicolumn{2}{|c|}{ Dry season } \\
\hline & & $\%$ Stations & $\%$ Sig. & $\%$ Stations & $\%$ Sig. & $\%$ Stations & $\%$ Sig. \\
\hline \multirow[t]{2}{*}{ All } & Negative & 21 & 0 & 11 & 0 & 79 & 0 \\
\hline & Positive & 79 & 0 & 89 & 11 & 21 & 0 \\
\hline \multirow[t]{2}{*}{$\mathrm{PC} 1$} & Negative & 50 & 0 & 25 & 0 & 100 & 0 \\
\hline & Positive & 50 & 0 & 75 & 0 & 0 & 0 \\
\hline \multirow[t]{2}{*}{ PC2 } & Negative & 0 & 0 & 0 & 0 & 56 & 0 \\
\hline & Positive & 100 & 0 & 100 & 11 & 44 & 0 \\
\hline
\end{tabular}


Figure 4. Heat maps showing running trends of precipitation for the most representative stations for PC1 and PC2. $X$ and $Y$-axes indicate the start and ending year, respectively, of the time slices for the trend analysis. The scale indicates the intensity of the trend based on Mann-Kendall's tau coefficient. Dots indicate a significant trend $(p<0.05)$.

clear trends, although there was a prevalence of negative (positive) coefficients for the wet (dry) seasons. In contrast, stations represented by $\mathrm{PC} 2$ showed predominantly positive coefficients (except for the dry season), although most were not statistically significant. However, the sign or significance of the trend varied depending on the period chosen. Figure 4 shows the running trends for the most representative stations for PC1 and PC2 (Pichilingue and Cañar stations, respectively; Table 2). Each pixel in the heat map depicts the Mann-Kendall's tau value for a time period, with the starting year indicated in the $x$-axis and the ending year indicated in the $y$-axis. The entire time series are also shown in the small embedded graphs. For PC1, positive coefficients predominated the annual and wet season precipitation, and negative coefficients predominated the dry season. Most coefficients were not significant, except for the wet season, for time slices around 1975-2010, when positive trends were observed. This effect was even more pronounced for $\mathrm{PC} 2$, where the trends become significant for annual and wet season precipitation in approximately the same time window, suggesting an intensification of positive trends in precipitation in recent decades.

\subsection{Temperature}

Figure 5 shows the PCs that summarize the variability of $T_{\max }$ across Ecuador. Three PCs explained most of 
Table 2. Locations of the meteorological stations used in the study.

\begin{tabular}{|c|c|c|c|c|c|c|c|c|c|}
\hline \multirow[t]{2}{*}{ Station name } & \multirow[t]{2}{*}{ Latitude } & \multirow[t]{2}{*}{ Longitude } & \multirow[t]{2}{*}{ Elevation } & \multicolumn{3}{|c|}{ Precipitation } & \multicolumn{3}{|c|}{ Temperature } \\
\hline & & & & Mean & SD & $\mathrm{PC}$ & Mean & SD & $\mathrm{PC}$ \\
\hline IZOBAMBA & -0.4 & -78.6 & 3058 & 1458.9 & 258.2 & 2 & 12.1 & 0.50 & 3 \\
\hline PORTOVIEJO-UTM & -1.0 & -80.5 & 46 & 523.1 & 321.9 & 1 & 26.3 & 0.61 & 2 \\
\hline PICHILINGUE & -1.1 & -79.5 & 120 & 2132.3 & 823.2 & 1 & 25.5 & 0.55 & 2 \\
\hline PUYO & -1.5 & -77.9 & 960 & 4590.8 & 549.9 & 3 & 21.7 & 0.48 & 1 \\
\hline LA CONCORDIA & 0.0 & -79.4 & 379 & 3238.6 & 960.4 & 1 & 24.5 & 0.59 & 2 \\
\hline PUERTO ILA & -0.5 & -79.3 & 319 & 2738.2 & 825.5 & 1 & 24.6 & 0.65 & 2 \\
\hline CAÑAR & -2.6 & -78.9 & 3083 & 481.8 & 113.7 & 2 & 12.0 & 0.48 & 3 \\
\hline LA ARGELIA-LOJA & -4.0 & -79.2 & 2160 & 946.9 & 182.0 & 2 & 16.4 & 0.55 & 1 \\
\hline MILAGRO(INGENIO VALDEZ) & -2.1 & -79.6 & 13 & 1379.0 & 781.3 & 1 & 25.6 & 0.62 & 2 \\
\hline EL ANGEL & 0.6 & -77.9 & 3000 & 768.1 & 273.6 & 2 & 11.9 & 0.74 & 1 \\
\hline SAN GABRIEL & 0.6 & -77.8 & 2860 & 994.4 & 211.2 & 2 & 12.0 & 0.55 & 1 \\
\hline OTAVALO & 0.2 & -78.3 & 2550 & 867.3 & 193.2 & 2 & 14.8 & 0.61 & 3 \\
\hline PAUTE & -2.8 & -78.8 & 2194 & 746.7 & 150.2 & 2 & 17.7 & 0.51 & 1 \\
\hline GUALACEO & -2.9 & -78.8 & 2230 & 779.3 & 181.4 & 2 & 17.2 & 0.59 & 1 \\
\hline SARAGURO & -3.6 & -79.2 & 2525 & 725.2 & 164.9 & 2 & 15.1 & 0.73 & 1 \\
\hline CARIAMANGA & -4.3 & -79.6 & 1950 & 1394.1 & 471.7 & 1 & 18.7 & 0.63 & 3 \\
\hline CELICA & -4.1 & -80.0 & 1904 & 1151.9 & 455.3 & 1 & 15.8 & 0.66 & 3 \\
\hline CHONE-U.CATOLICA & -0.7 & -80.0 & 36 & 1271.8 & 576.6 & 1 & 26.1 & 0.65 & 2 \\
\hline ZARUMA & -3.7 & -79.6 & 1100 & 1269.3 & 378.0 & 1 & 22.9 & 0.62 & 1 \\
\hline
\end{tabular}
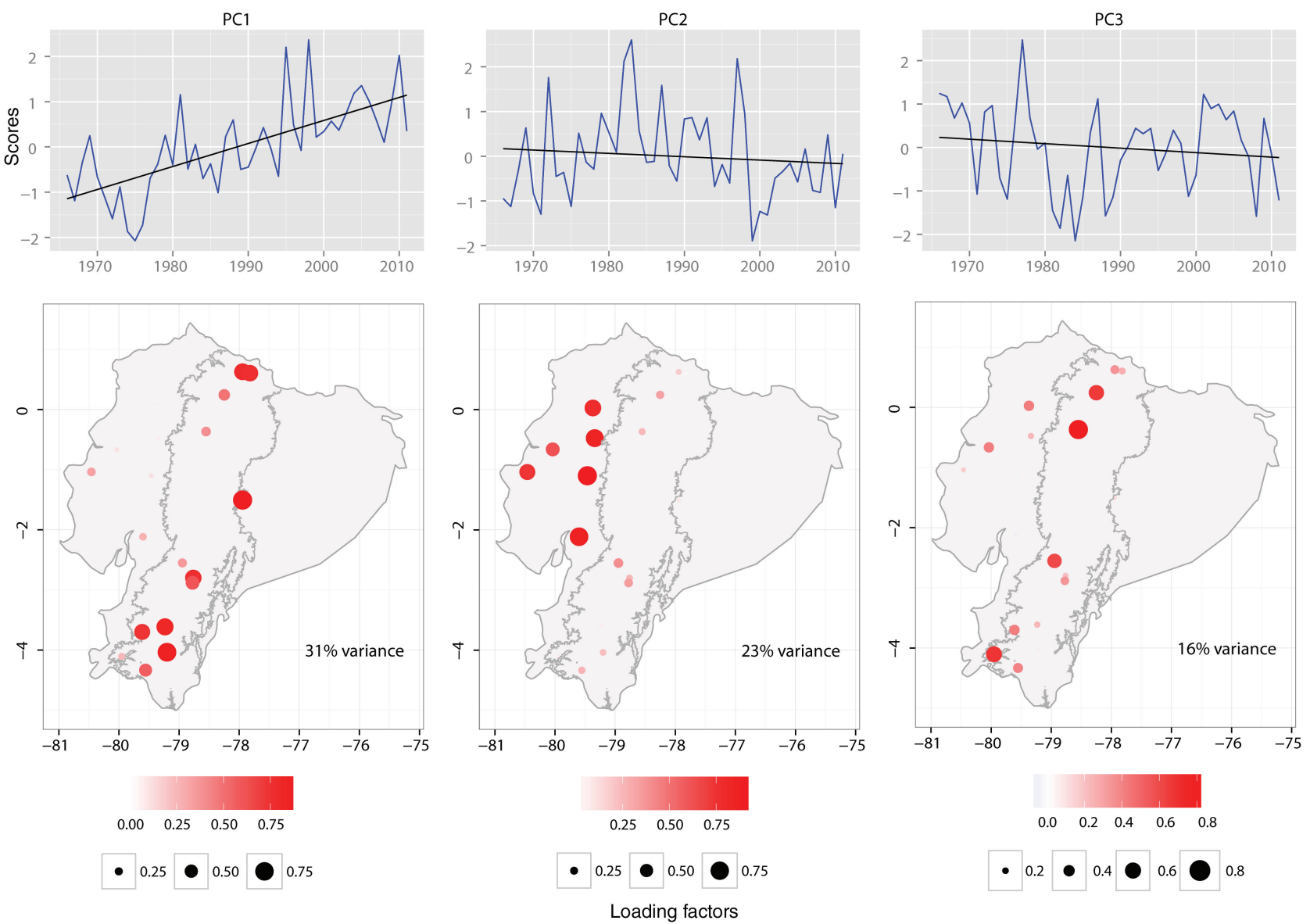

Figure 5. Spatial and temporal variability of maximum temperature. Upper panels show the factorial scores for the PCs obtained. Lower panels show the loading factors of precipitation series with each PC. The scale indicates the intensity and sign, and the point size indicates the absolute values for the loading factors. Spatial extent of the Andean chain is depicted by a contour line at $1000 \mathrm{~m}$ asl. 
Table 3. Percentage of stations showing negative and positive tau coefficients and significant trends in $T_{\max }$ (a) and $T_{\min }$ (b).

\begin{tabular}{|c|c|c|c|c|c|c|c|}
\hline & \multirow[t]{2}{*}{ Tau sign } & \multicolumn{2}{|c|}{ Annual } & \multicolumn{2}{|c|}{ Wet season } & \multicolumn{2}{|c|}{ Dry season } \\
\hline & & $\begin{array}{c}\% \\
\text { Stations }\end{array}$ & $\begin{array}{c}\% \\
\text { Sig. }\end{array}$ & $\begin{array}{c}\% \\
\text { Stations }\end{array}$ & $\begin{array}{c}\% \\
\text { Sig. }\end{array}$ & $\begin{array}{c}\% \\
\text { Stations }\end{array}$ & $\begin{array}{r}\% \\
\text { Sig }\end{array}$ \\
\hline \multicolumn{8}{|c|}{ (a) $T_{\max }$} \\
\hline & Negative & 16 & 0 & 32 & 0 & 5 & 0 \\
\hline & Positive & 84 & 37 & 68 & 32 & 95 & 37 \\
\hline \multirow[t]{2}{*}{ PC1 } & Negative & 0 & 0 & 0 & 0 & 0 & 0 \\
\hline & Positive & 100 & 78 & 56 & 67 & 44 & 78 \\
\hline \multirow[t]{2}{*}{ PC2 } & Negative & 5 & 0 & 67 & 0 & 17 & 0 \\
\hline & Posit & 50 & 0 & 33 & 0 & 83 & 0 \\
\hline \multirow[t]{2}{*}{ PC3 } & Negative & 0 & 0 & 50 & 0 & 0 & 0 \\
\hline & Positive & 100 & 0 & 50 & 0 & 100 & 0 \\
\hline \multicolumn{8}{|c|}{ (b) $T_{\min }$} \\
\hline \multirow[t]{2}{*}{ All } & Negative & 0 & 0 & 0 & 0 & 0 & 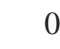 \\
\hline & Positive & 100 & 84 & 100 & 74 & 100 & 84 \\
\hline \multirow[t]{2}{*}{ PC1 } & Negative & 0 & 0 & 0 & 0 & 0 & 0 \\
\hline & Positive & 100 & 100 & 100 & 88 & 100 & 88 \\
\hline \multirow[t]{2}{*}{ PC2 } & Negative & 0 & 0 & 0 & 0 & 0 & 0 \\
\hline & Positive & 100 & 71 & 100 & 71 & 100 & 71 \\
\hline \multirow[t]{2}{*}{ PC3 } & Negative & 0 & 0 & 0 & 0 & 0 & 0 \\
\hline & Positive & 100 & 75 & 100 & 50 & 100 & 100 \\
\hline
\end{tabular}

the original variance and showed a spatial pattern similar to the PCs for precipitation. PC1 explained $31 \%$ of the original variance and grouped stations located along the Andean mountain chain (more or less the same stations for $\mathrm{PC} 2$ in the analysis of precipitation). The factorial scores showed a trend of steeply increasing temperature at these stations. PC2 explained $23 \%$ of the variance and grouped stations located in the lowlands near the coastline; these were largely the same stations for PC1 in the analysis of precipitation. No clear trend was evident among these stations during the entire study period, although a trend of increase (decrease) was observed during the first (last) decades of the period. PC3 represented several stations in the Andean chain that were not represented by PC1. For these stations, no clear trend was evident for the entire period, although trends of partial increase and decrease were apparent. Table 3a summarizes the trends for all stations, sorted by both season and PC. In general, the observed trends confirmed the pattern shown in Figure 5, with a predominance of significant increasing $T_{\max }$ for stations represented by $\mathrm{PC} 1$ and no significant coefficients for the other stations. No substantial differences were observed between trends in $T_{\max }$ during the wet and the dry seasons. Figure 6 shows the running trends in $T_{\max }$ of the most representative stations for each PC (Puyo, Pichilingue and Izobamba stations, Table 2). For PC1, significant trends of increase in temperature were found for all time windows, although slightly less steep for the wet seasons. For PC2, a clear break point was observed in approximately 1975, following which a significant decrease in $T_{\max }$ was observed. In general, insignificant positive trends were observed for PC3, except for the dry season when trends of increasing $T_{\max }$ were evident, especially for the time windows towards the end of the period.
Figure 7 shows the spatio-temporal variability of $T_{\text {min }}$ across Ecuador. The spatial structure of the PCs was similar to that observed for $T_{\max }$, with stations grouped in three PCs. The evolution of $T_{\min }$ in the three PCs showed a general trend of increase superimposed on strong inter-annual variability, which clearly differed among the three PCs. From Table 3b, it is evident that almost all stations showed a significant increase in $T_{\text {min }}$ but with a slightly lower percentage evident for the wet seasons. The heat maps in Figure 8 show the running trends for time windows for the stations most representative of each PC. For most time windows, PCs and seasons, the positive $T_{\min }$ trends were significant, except for some time windows in PC1.

\subsection{ENSO control on precipitation and temperature}

Figure 9 shows the correlation coefficients between the precipitation series and the El Niño 1+2 (Figure 9(a)) and El Niño 3.4 (Figure 9(b)) series. The maps show that the correlation values had the same spatial pattern as in the PCA. In general, the stations located near the coastline showed positive and strong correlations between precipitation and El Niño 1+2, whereas correlations with El Niño 3.4 were slightly weaker. In contrast, the stations located in the Andes showed no correlation with El Niño 1+2 and a negative correlation with El Niño 3.4. Correlations for the entire series (including all months consecutively) were not very strong (albeit significant in many cases) as the precipitation in some months was not correlated with either the El Niño $1+2$ or El Niño 3.4. This was assessed in detail using heat maps showing correlations between the detrended precipitation in each month and the circulation indices at different levels of monthly aggregation (backwards) for the most representative stations of PC1 and PC2 (see Section 4.1). Thus, PC1 precipitation (coastal stations) showed a significant positive correlation with El Niño 1+2 from March to December. The effect of the ENSO on coastal precipitation was evident in the same month as the ENSO anomalies, as the maximum correlation for monthly precipitation was recorded in the 1-month El Niño 1+2. However, the El Niño 1+2 also showed some predictive capacity for precipitation based on significant correlations with El Niño 1+2 at different aggregation levels (up to 12 months). Stations represented by PC2 showed little correlation with El Niño 1+2. The signal of El Niño 3.4 on precipitation was less evident than that of El Niño $1+2$ in the coastal region but stronger in the Andes. For PC1, the signal commenced in April and was maintained until December. Moreover, the signal was stronger for the El Niño 3.4 values aggregated some months in advance. Precipitation variability at the stations represented by PC2 was partially explained by El Niño 3.4, especially for precipitation in January, July, August and September.

Figures 10 and 11 show the correlation for $T_{\max }$ and $T_{\min }$ with each ENSO index, respectively. As with precipitation, a positive relationship was found between El Niño $1+2 /$ El Niño 3.4 and $T_{\max } / T_{\min }$. These relationships were especially significant for the first half of the year, although El Niño 3.4 also showed significant correlations in various 

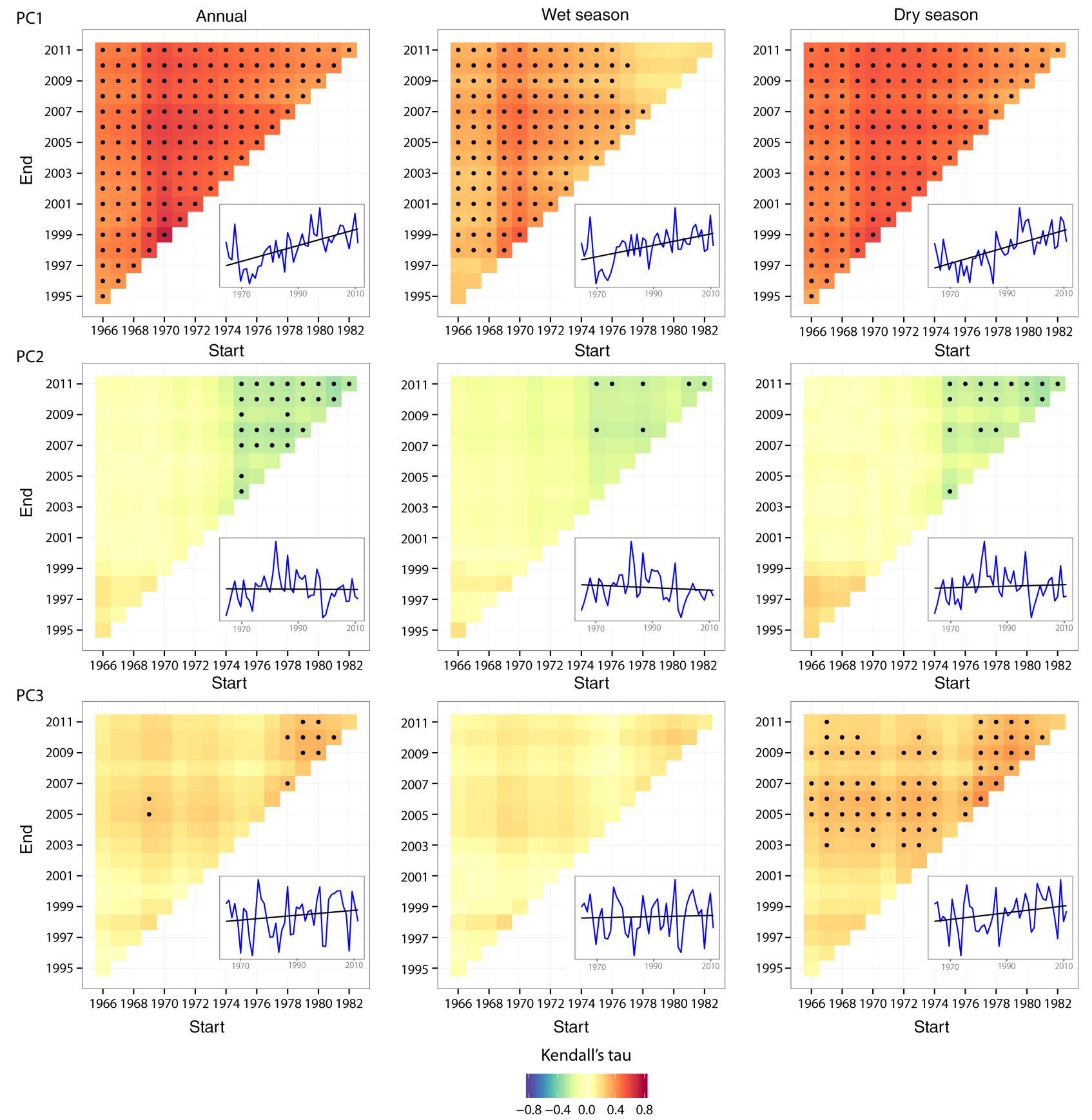

Start

Figure 6. Heat maps showing running trends of maximum temperature for the most representative stations for PC1, PC2 and PC 3. $x$ - and $y$-axes indicate the start and ending year, respectively, of the time slices for the trend analysis. The scale indicates the intensity of the trend based on Mann-Kendall's tau coefficient. Dots indicate a significant trend $(p<0.05)$.

months during the second half of the year. However, in the case of temperatures, there was no clear spatial correspondence between the PCs (Figure 5) and the level of correlation. In fact, the internal structure of monthly correlations (heat maps) showed no clear differences among the three PCs, contrary to what was found for precipitation. Moreover, the fact that correlations were computed on the detrended series of temperature indicates that the strong relationship found between the ENSO and temperature for certain months of the year was independent of the warming experienced in the region during recent decades.
The control that the ENSO exerted on precipitation and temperature implied, in practical terms, that during the peaks of the phenomenon, the climatic conditions markedly deviated from the average. To demonstrate this, the mean precipitation (Figure 12) and temperature (Figure 13) during warm events (El Niño), cold events (La Niña) and months with 'neutral conditions' (see Section 3.1) were calculated according to the coastal index El Niño 1+2 and the central pacific index El Niño 3.4. Figure 12 shows that for the wet season and only for stations represented by PC1 (the coastal region), precipitation during El Niño events according to the El Niño 

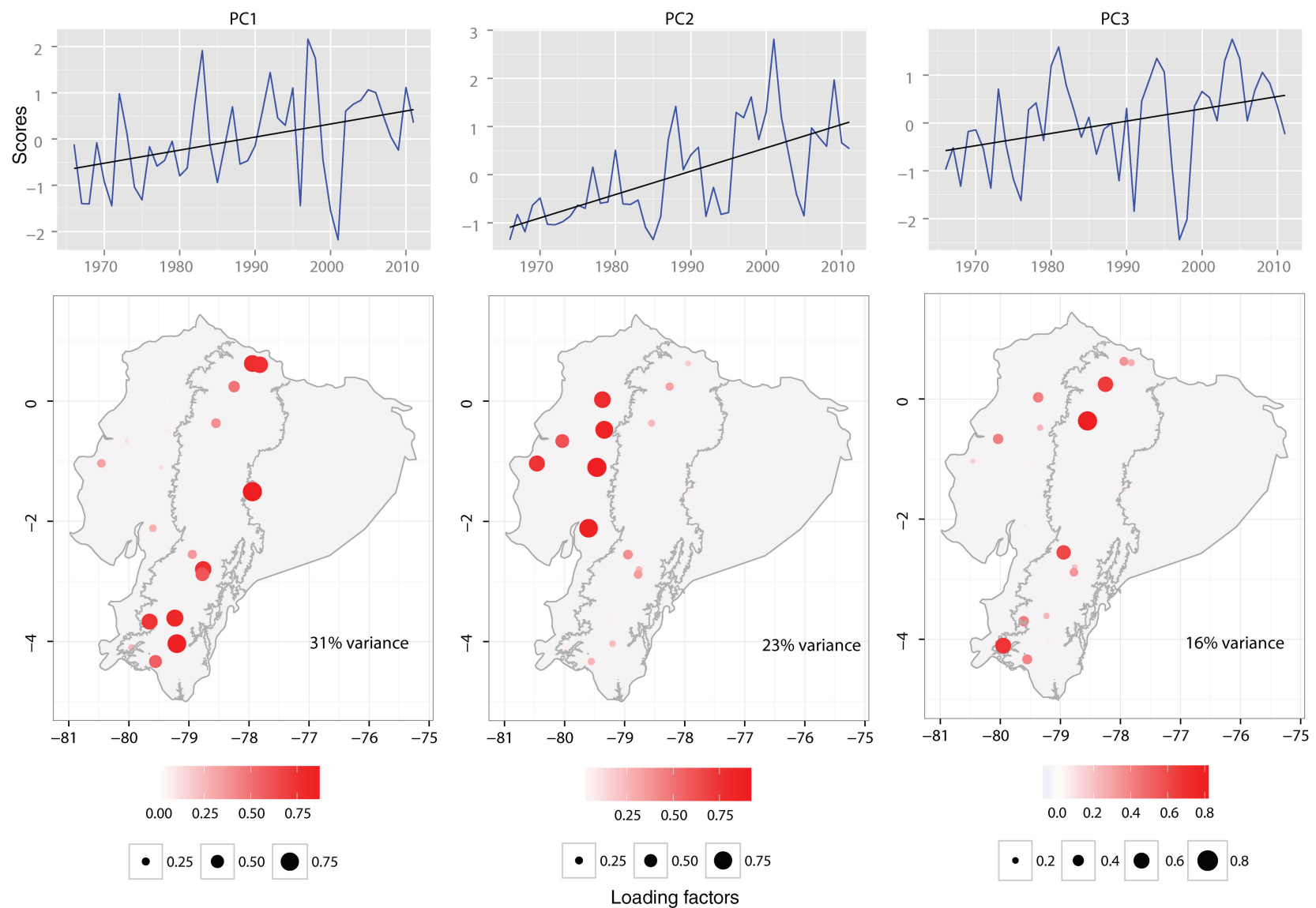

Figure 7. Spatial and temporal variability of minimum temperature. Upper panels show the factorial scores for the PCs obtained. Lower panels show the loading factors of precipitation series with each PC. The scale indicates the intensity and sign, and the point size indicates the absolute values for the loading factors. Spatial extent of the Andean chain is depicted by a contour line at $1000 \mathrm{~m}$ asl.

$1+2$ (Figure 12(a)) index was double than during normal months. During La Niña events, precipitation was less than average and almost a factor of three less than during El Niño events. Precipitation in the Andes region (PC2) shows little difference according to El Niño 1+2, but it does show significant differences according to El Niño 3.4 (Figure 12(b)). In this case, the effect of the ENSO on precipitation is the opposite than for the coastal region, i.e. during El Niño events, precipitation shows below-average values, whereas La Niña events are associated to precipitation higher than average. During the dry season, the differences between events were exacerbated for the coastal region according to El Niño $1+2$ and in the Andes according to El Niño 3.4. It must be taken into account that the high values of precipitation shown in Figure 12 might be markedly influenced by two extreme El Niño events that took place in 1982-1983 and 1997-1998 (in these intense events, the ENSO is equally explained by El Niño $1+2$ and El Niño 3.4, indicating the large areal extent of the episodes), during which historical maximum levels of precipitation were recorded (see Figure 3, PC1). Thus, for the small embedded boxplots in Figure 12, those extreme events were removed from the analysis; this showed that the differences were less, but the pattern was still evident.

Temperature (Figure 13) showed the same pattern as precipitation but with smaller differences. Only significant differences were observed at stations represented by PC2 (coastal stations) and by El Niño $1+2$ (Figure 13(a)), whereas at the Andes stations, the differences were more subtle. From Figures 10 and 11, it appears that the effect of the ENSO on temperature was independent of the location of stations, but in Figure 13, it was noticed mainly at the coastal stations where the magnitude of temperatures clearly differed amongst the ENSO events.

\section{Discussion and conclusions}

From the available climate data, two main regions of Ecuador were identified in terms of variability of precipitation and temperature: the coastal region and the Andean region. Because of lacking data availability, the present study was able to include data for only one station located on the Amazonian side of the Andes. This station showed a contrasting evolution of precipitation, and it is hypothesized that if more stations had been available in the Amazonian basin, a third climatic region may well have been distinguished.

In terms of climate trends, precipitation along the coast showed no particular trend, whereas precipitation at stations located in the Andean mountain chain showed trends of increasing precipitation; these were significant 

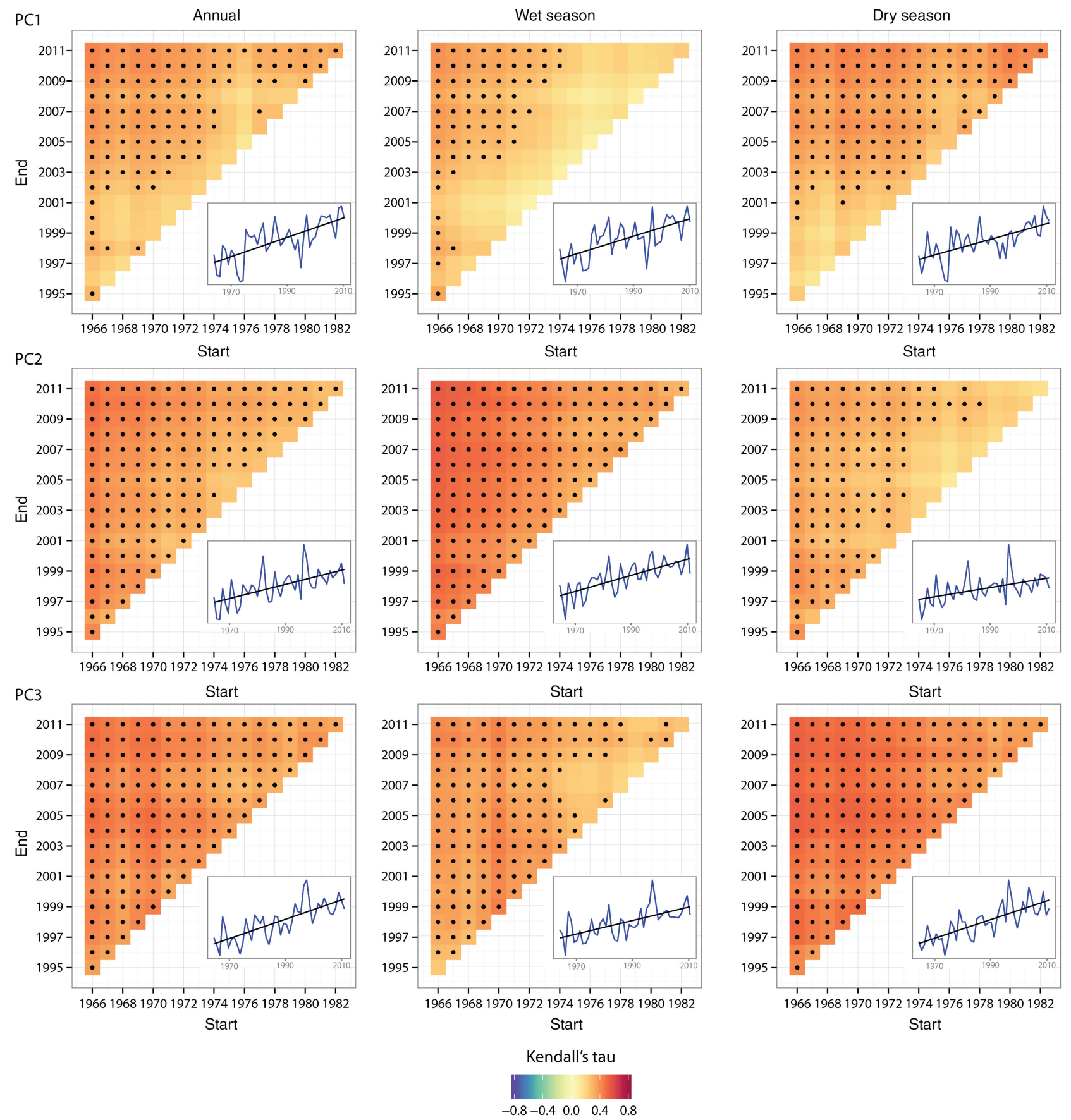

Figure 8. Heat maps showing running trends of minimum temperature for the most representative stations for PC1, PC2 and PC $3 . x$ - and $y$-axes indicate the start and end year, respectively, of the time slices for the trend analysis. The scale indicates the intensity of the trend based on Mann-Kendall's tau coefficient. Dots indicate a significant trend $(p<0.05)$.

for the time slices starting in the mid-1970s, especially during the wet season. This is in agreement with the increasing trend observed by Haylock et al. (2006) in most daily rainfall indices over Ecuador and northern Peru as well as over Brazil, Paraguay, Uruguay and northern and central Argentina (in contrast to a decrease in precipitation in southern Peru and southern Chile). The authors related such trends in regional rainfall to a general decrease of the SOI (sea level pressure anomalies between Taihti and Darwin); this is inconsistent, however, with the present study's results as more frequent El Niño conditions related to negative SOI values would involve a decrease in precipitation in the Ecuadorian Andes, as observed in here. However, the SOI presents some weaknesses as an indicator of the ENSO and precipitation variability over the South American continent and more specifically over Ecuador. This is mainly because the sea level pressures at Taihti are not necessarily representative of the pressure gradients over the eastern Pacific and because Taihti and Darwin are not located over the equator but somewhat south of it $\left(18^{\circ} \mathrm{S}\right.$ and $12^{\circ} \mathrm{S}$, respectively). There is evidence of an uncoupling between the SOI and the ENSO indices 
(a)

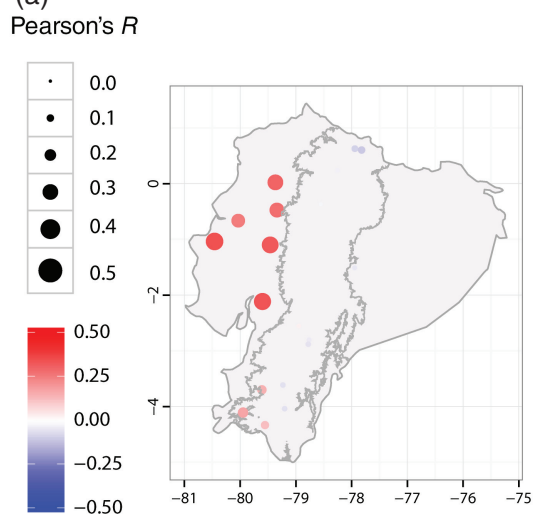

(b)

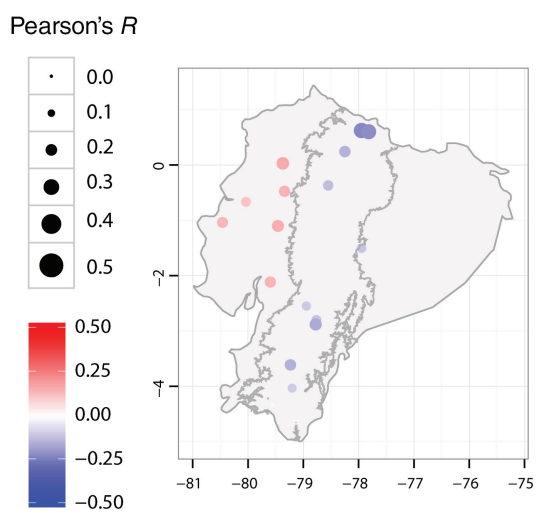

PC1

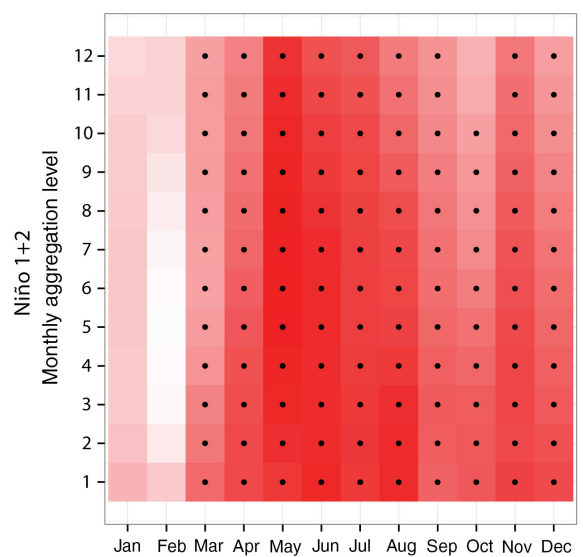

PC2

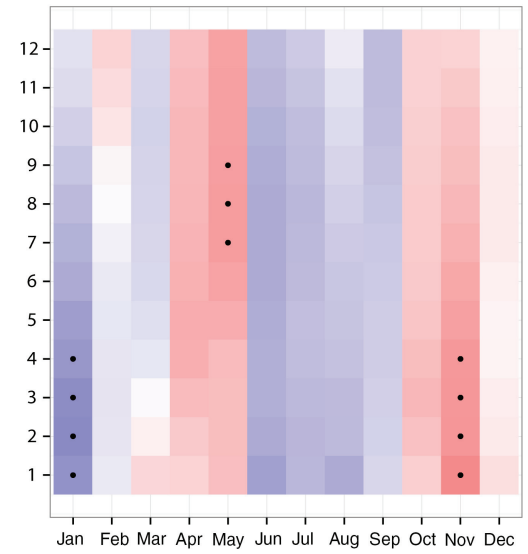

Pearson's $R$ $-0.8-0.4 \quad 0.0 \quad 0.4 \quad 0.8$

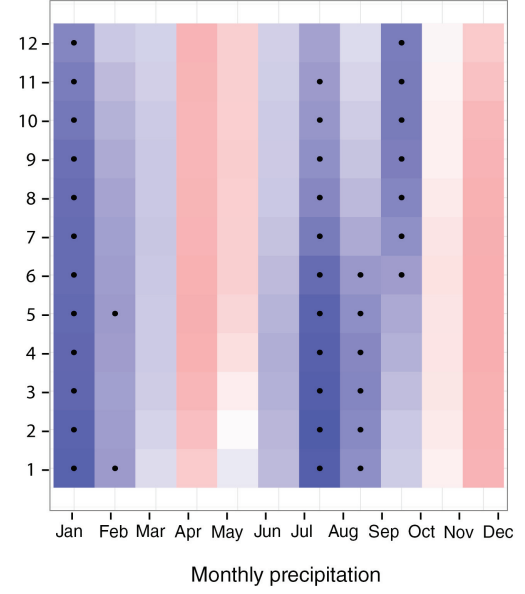

Figure 9. Correlations of precipitation with the El Niño 1+2 (a) and El Niño 3.4 (b). Maps show the correlation for all stations and for the entire time series (circle size: absolute value). Heat maps show the correlation for stations representative of PC1 and PC2 at the monthly level; that is, correlations of monthly detrended precipitation with the teleconnection indices at various levels of monthly aggregation (averages up to 12 months). Dots indicate significant correlations.

during the last decade (Takahashi, K., 2015, personal communication), which prevents the discussion of any recent trend of precipitation over South America based on such indicator. Further research is necessary to clarify the causes of both the variability and trends found in Andean precipitation; this may have important implications for water resources and glacier survival in a warmer climate.

Although there were differing patterns of inter-annual evolution in temperature across Ecuador, there was a strong trend of increase during the study period. However, differences in trends were evident for the minimum and maximum temperatures. For $T_{\min }$, the trend was homogeneous for the entire country (particularly strong for the coastal stations), but for $T_{\max }$, there was substantial spatial heterogeneity with trends of temperature decrease in the coastal region and a strong trend of temperature increase throughout most of the Andean region. Temperatures were significantly correlated with the El Niño $1+2$ index, especially in the western lowlands, and to a lesser extent with El Niño 3.4; however, the positive trend appeared to be independent of the ENSO phenomenon and may therefore have been a consequence of global warming caused by increased greenhouse gases. The mean ratio of increase of approximately $0.25^{\circ} \mathrm{C}$ per decade (data not shown) is within the range of warming ratios reported for various regions of the tropical Andes, including 0.11 and $0.10^{\circ} \mathrm{C}$ per decade for the Bolivian and Peruvian Andes, respectively (Casimiro et al., 2013; Seiler et al., 2013) and $0.32^{\circ} \mathrm{C}$ for the tropical Andes for the period 1974-1998 (Vuille and Bradley, 2000). Warming is expected to continue in the region, with the main threat to the environment and societies being related to the retreat of glaciers, with subsequent effects on the availability (an increase in the short-term, but a decrease in the long-term) of fresh water for downstream populations (Bradley et al., 2006) and also an increase in the atmospheric water demand, which may affect water stress in crops and natural vegetation.

With respect to climate variability, precipitation along coastal Ecuador was observed to be strongly correlated with the El Niño 1+2 index. The two periods of heavy precipitation (1982-1983 and 1997-1998) correspond to two of the most extreme El Niño events recorded (Rein, 
(a)



PC2

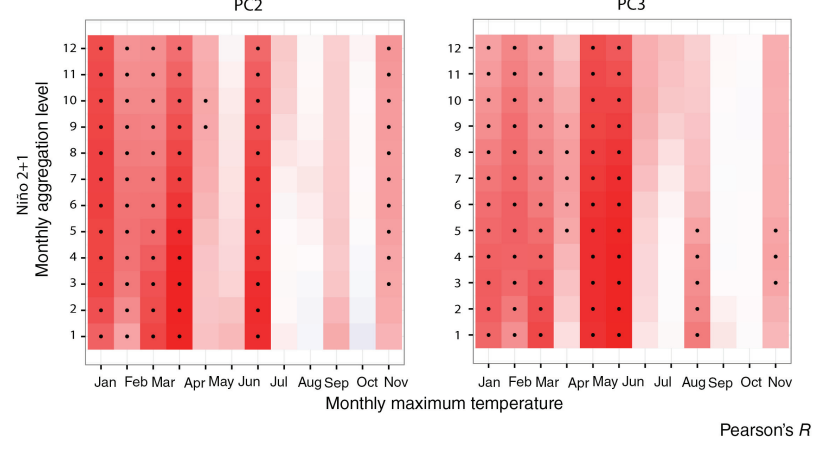

(b)

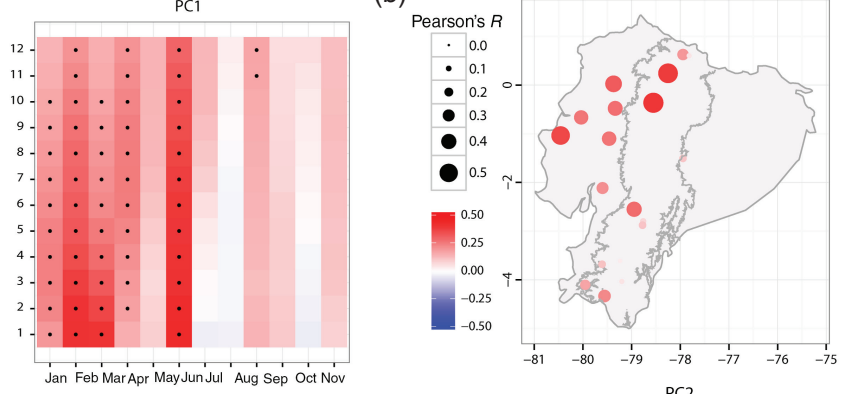

PC2

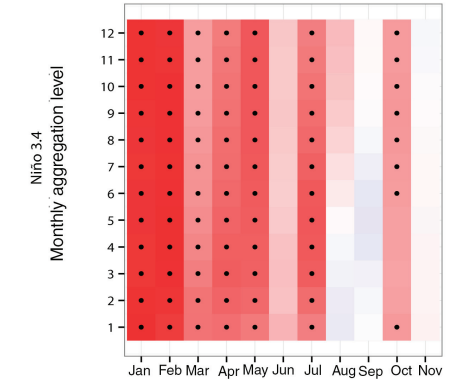

Monthly maximum temperature

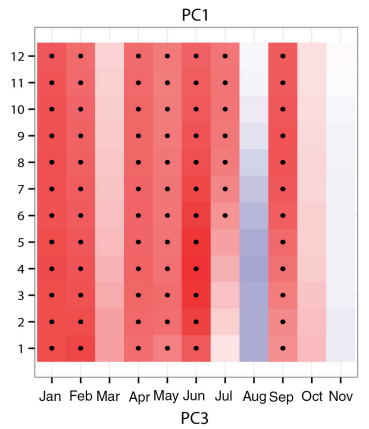

$\mathrm{PC} 3$

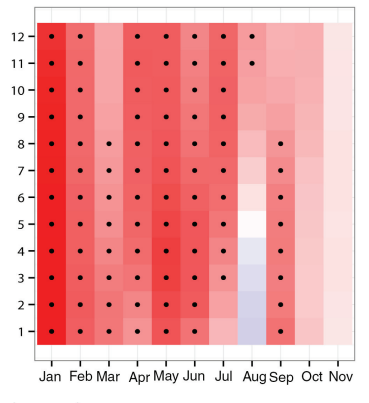

$\begin{array}{lll}-0.5 & 0.0 & 0.5\end{array}$

Figure 10. Correlations of maximum temperature with the El Niño 1+2 (a) and El Niño 3.4 (b). Maps show the correlation for all stations and for the entire time series (circle size: absolute value). Heat maps show the correlation for stations representative of PC1 and PC2 at the monthly level; that is, correlations of monthly detrended precipitation with the teleconnection indices at various levels of monthly aggregation (averages up to 12 months). Dots indicate significant correlations.

2007). The influence of the ENSO was stronger during the dry season (June-November) than during the wet season (December-May). Unlike in the coastal region, El Niño $1+2$ does not explain precipitation in the Andes; however, there was a signal of El Niño 3.4. This is a clear example of how the El Niño 1+2, which is based on SST from the region near the coasts of Peru and Ecuador, is a robust index for characterizing the short-term ENSO and related precipitation caused by local convection in the coastal regions. In contrast, the El Niño 3.4 characterizes the SST in the central Pacific and reflects the signal of more general mid-troposphere circulation in the Pacific region and the effects of anomalous Walker circulation during ENSO events. Thus, it is a better predictor of precipitation variability for inland and highland regions such as the Andes. However, the correlations found between precipitation and El Niño 3.4 in the Andes were not as strong as those between El Niño 1+2 and coastal precipitation. The reason for this is that other sources of variability affect precipitation in the Andes. The present study did not explore the decadal variability associated to the PDO. However, a spectral analysis performed over the two PCs (data not shown) reveals the sign of two sources of variability: PC1 depicts a frequency peak at 4.8-year periods, indicating the inter-annual sign of ENSO variability, and a secondary peak at 12 -year periods, related to the decadal variability of the PDO. On the contrary, PC2 shows the opposite signal, the main peak of frequency at 16 -year periods (decadal variability) and a secondary peak at 5-year periods (ENSO variability), indicating that the PDO may be a better modulator of Andean precipitation than the ENSO.
The impact of ENSO on precipitation in South America is well known: warmer than usual Pacific region SSTs (El Niño) trigger convection in coastal regions, leading to large precipitation events, especially on the coast of Ecuador and Peru. This is enhanced by the weakened South Pacific trade winds, which allow the ITCZ to migrate to the south and to transport warm moist air to the coastal area (Rossel and Cadier, 2009). On the other hand, the enhanced coastal convection leads to intense subsidence over Brazil and Central America, which suppresses deep tropical convection and leads to negative rainfall anomalies and drought conditions over the remainder of the continent (Grimm et al., 2000; Coelho et al., 2002; Poveda et al., 2006). However, other atmospheric circulation mechanisms must be taken into account while explaining precipitation variability in this region. For example, Bazo et al. (2013) found that precipitation in the northwestern part of Peru is explained not only by the ENSO but also by other modes of variability including the Indian Ocean Dipole or the equatorial Atlantic Oscillation. The inner complexity of the ENSO phenomenon must also be considered as evidenced by the numerous ENSO regions that have been defined (El Niño 1+2, El Niño 3, El Niño 4, El Niño 3+4), the contrasting effects in different regions and its complex variability involving different recognizable ENSO modes (El Niño and El Niño Modoki, e.g.: Ashok et al., 2007; Takahashi et al., 2011). Moreover, the effect of the ENSO on the precipitation in the region is far from being stationary; the overlapping of ENSO events with the PDO could partially explain recent changes in the temporal and spatial ENSO effects over the Andes; thus, whether the PDO 

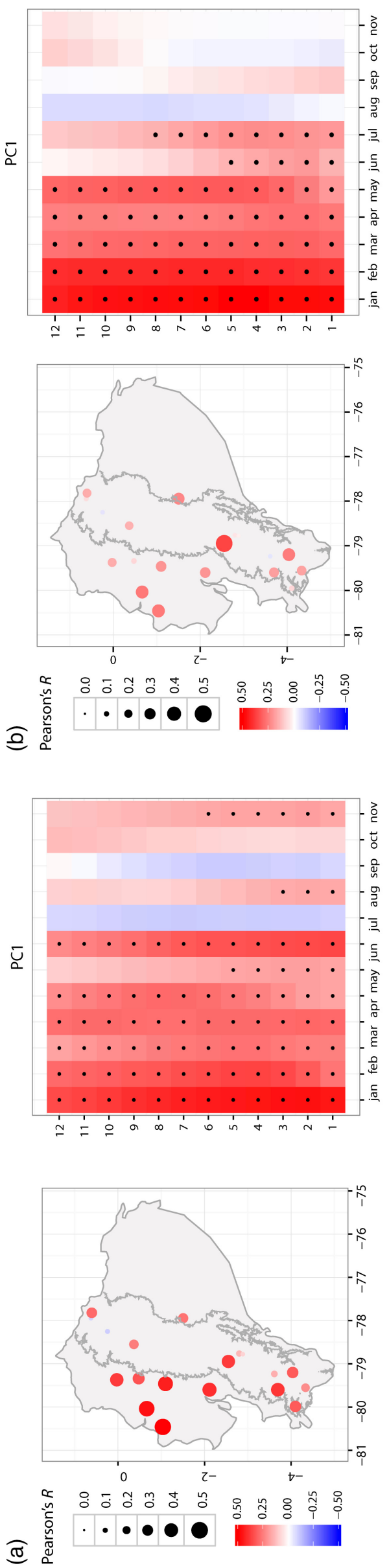
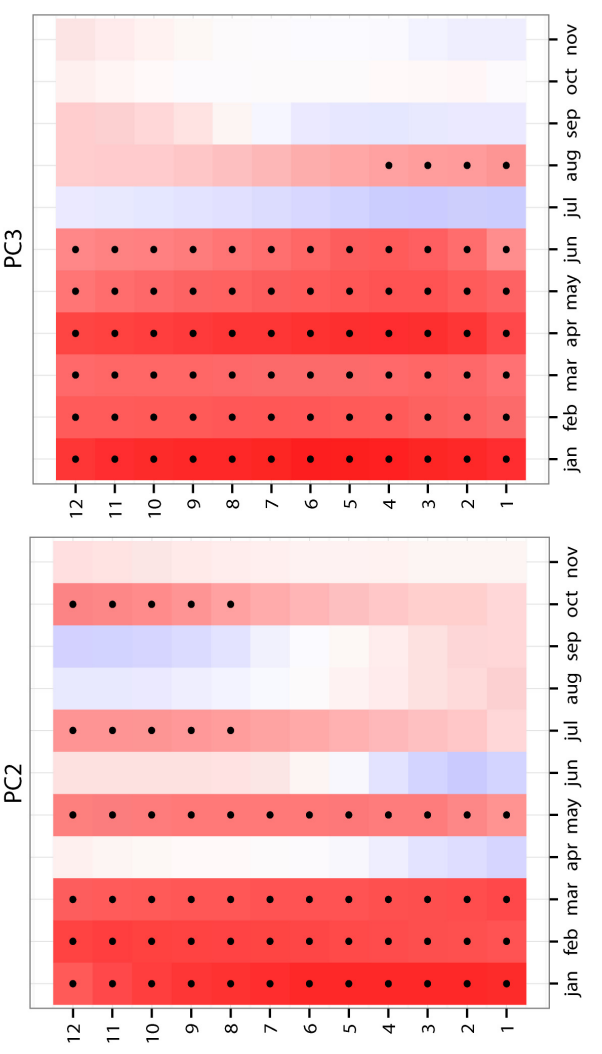

рәләр иопребәдббе КІчдиош $\neg$ ๑ Ou!n

(a)



Dry season
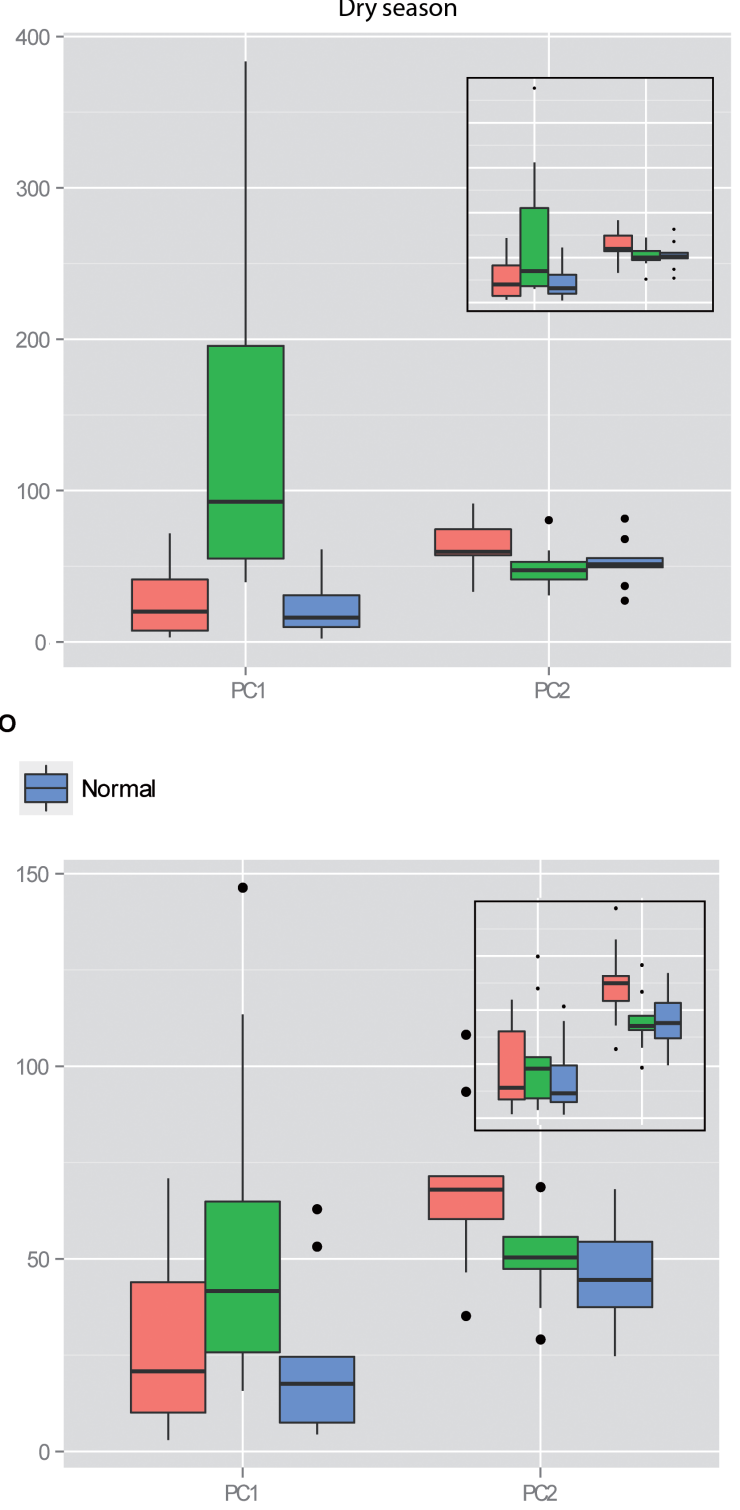

(b)

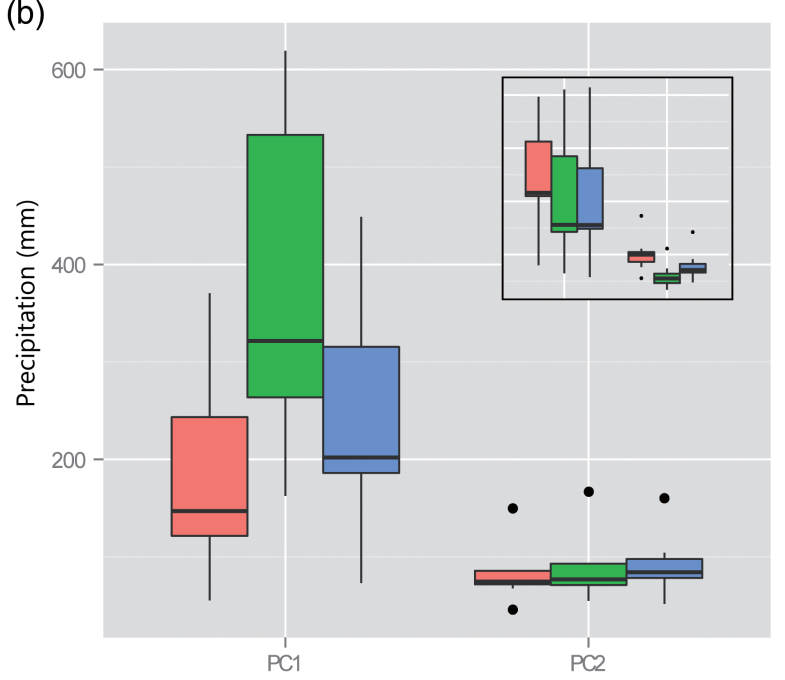

Figure 12. Differences in precipitation during El Niño events, La Niña events and 'normal' months according to El Niño 1+2 (a) and El Niño 3.4 (b) indices. Small embedded boxplots show the differences following removal of the extreme El Niño events of 1982-1983 and 1997-1998. Boxplots show the 10th, 25th, 50th, 75th and 90th quantiles.

is in its cold or warm phase, the impacts of the ENSO on precipitation can be reduced or enhanced (Garreaud et al., 2009; Herzog et al., 2011).

The present study complements the findings of various studies carried out in the tropical Andes and adjacent regions and contributes to the identification of the main characteristics of climate variability and current trends in the region, especifically for Ecuador. Previous studies focused on different aspects of climate variability that the present study addressed here. For example, Vuille et al. (2000) studied the variability of temperature and precipitation in a large set of meteorological stations across the Ecuadorian Andes for the period 1963-1992. Similar to the present study, they found that El Niño (La Niña) years were associated with below-average (above-average) precipitation, which is a common feature on other inland regions (Poveda et al., 2006), and just the opposite of what happens in the coastal region. Rossel and Cadier (2009) focused on the coast of Ecuador for the 1964-1993 period and found El Niño a good predictor of precipitation but stressed the necessity of using longer records in order to confirm the strength of the relationship. Others, such as Espinoza-Villar et al. (2009) in a regional study of the Amazonian basin, found, in terms of precipiation, a long-term decrease during 1975-2003, which was not observed for any of the precipiation records in the present study. The latter studies either focused on a restricted region of Ecuador and a partial spatio-temporal characteristic of the climate or lacked data from the last 10 years. In this sense, the present study puts together the analysis of temporal variability and trends with spatial variability and their association with the ENSO in the entire continental Ecuador. Also, the present study's updated climate data informs on the recent variability and 
(a)

(a)



(b)



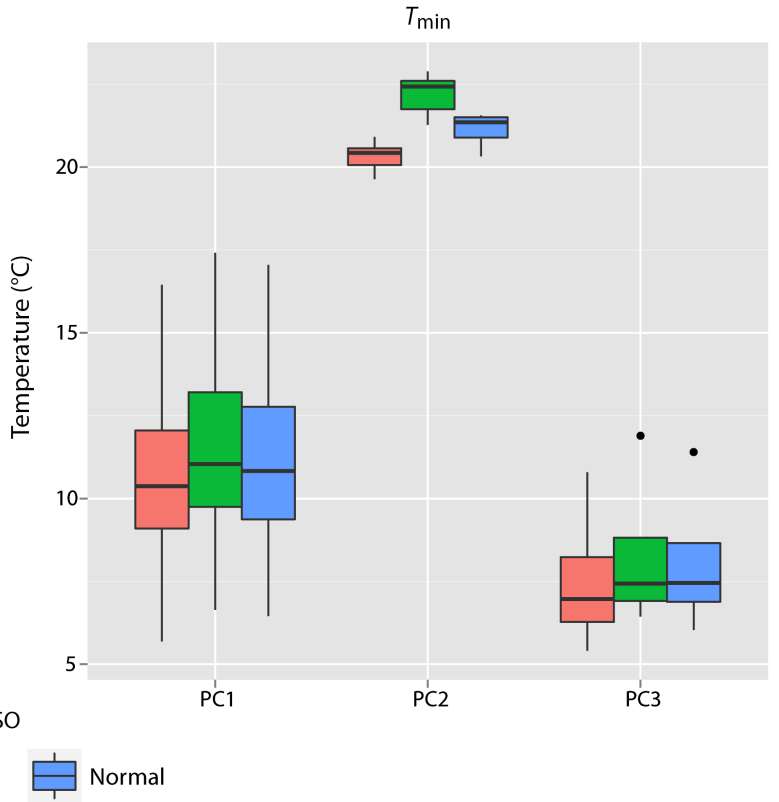

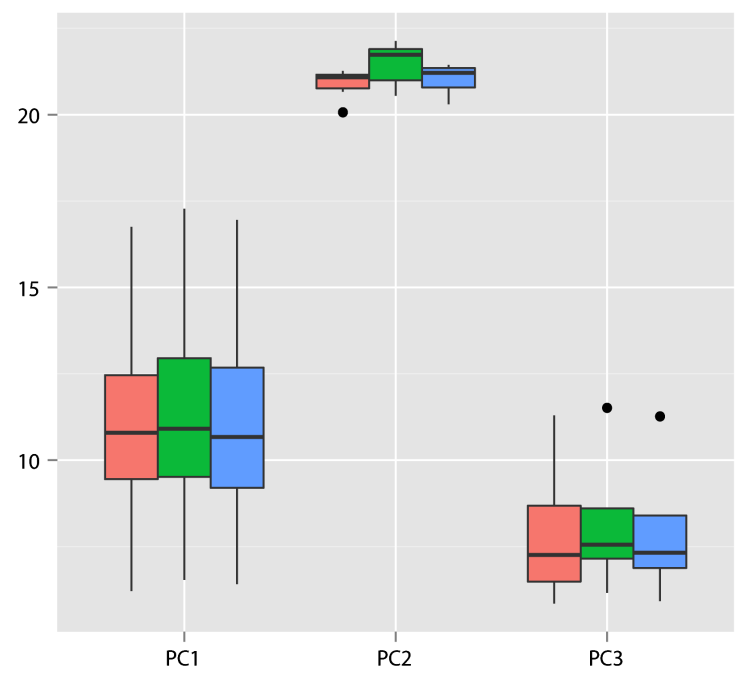

Figure 13. Differences in temperature during El Niño events, La Niña events and 'normal' months according to El Niño $1+2$ (a) and El Niño 3.4 (b) indices. Boxplots show the 10th, 25th, 50th, 75th and 90th quantiles.

trends of precipitation and temperature. In this regard, the present study's multi-period trend analysis advances the understanding of climate trends in the region, indicating a recent enhancement of precipitation and a differing behaviour of maximum and minimum temperature, with the first showing a slight hiatus during the last decade of the long-term observed warming. Ongoing research should focus on understanding the different sources of variability and the hydrological/environmental implications of the observed and future trends on the climate of Ecuador.

\section{Acknowledgements}

This work was supported by the projects "Creación de una base de datos climática de calidad para el estudio del cambio climático de las montañas del Peru-COOPB20042" and 'Test multisectorial y actividades demostrativas sobre el potencial desarrollo de sistemas de monitorización de sequías en tiempo real en la región del oeste de Sudamérica-I-COOP H2O 2013CD0006', both funded by the CSIC (Spanish Research Council). We thank the Ecuador National Institute for Meteorology and Hydrology (Instituto Nacional de Meteorología e Hidrología, INAMHI) and the International Research Center on EL Niño (Centro Internacional para la Investigación del Fenómeno de El Niño, CIIFEN) for providing and pre-processing the climate data used in this work. ASL was supported by the postdoctoral fellowship JCI-2012-12508.

\section{References}

Aguilar E, Auer I, Brunet M, Peterson TC, Wieringa J. 2003. Guidelines on climate metadata and homogenization, WMO-TD No. 1186, World Meteorological Centers, Geneva, Switzerland, 52 pp.

Ashok K, Behera SK, Rao SA, Weng H, Yamagata T. 2007. El Niño Modoki and its possible teleconnection. J. Geophys. Res. 112: C11007. 
Bazo J, Lorenzo M, Rosmeri P. 2013. Relationship between monthly rainfall in NW Peru and tropical sea surface temperature. Adv. Meteorol. 2013: 9.

Bendix A, Bendix J. 2006. Heavy rainfall episodes in Ecuador during El Nino events and associated regional atmospheric circulation and SST patterns. Adv. Geosci. 6: 43-49.

Bradley RS, Vuille M, Diaz HF, Vergara W. 2006. Threats to water supplies in the tropical Andes. Science 312(5781): 1755-1756.

Bronaugh D, Werner A. 2013. zyp: Zhang + Yue-Pilon trends package. $\mathrm{R}$ package version 0.10-1. http://CRAN.R-project.org/package=zyp (accessed 28 July 2015).

Buytaert W, Celleri R, Willems P, Bièvre B, Wyseure G. 2006. Spatial and temporal rainfall variability in mountainous areas: a case study from the south Ecuadorian Andes. J. Hydrol. 329: 413-421.

Carmona AM, Poveda G. 2014. Detection of long-term trends in monthly hydro-climatic series of Colombia through empirical mode decomposition. Clim. Change 123: 301-313.

Casimiro WSL, Labat D, Ronchail J, Espinoza JC, Guyot JL. 2013. Trends in rainfall and temperature in the Peruvian Amazon-Andes basin over the last 40 years (1965-2007). Hydrol. Processes 27: 2944-2957.

Caussinus H, Mestre O. 2004. Detection and correction of artificial shifts in climate series. J. R. Stat. Soc. Ser. C53: 405-425.

Coelho CAS, Uvo CB, Ambrizzi T. 2002. Exploring the impacts of the tropical Pacific SST on the precipitation patterns over South America during ENSO periods. Theor. Appl. Climatol. 71: 185-197.

CPC-NOAA. 2006. Climate Prediction Center (CPC) Oceanic Nino Index. Climate Climate Prediction Center, National Centers for Environmental Prediction, National Weather Service, NOAA, U.S Department of Commerce. http://catalog.data.gov/harvest/object/ 2ad059f0-41ad-4446-ae5f-17bc1d19c972/html/original (accessed 25 August 2014).

ENFEN. 2012. Definición Operacional de los eventos El Niño y la Niña y sus magnitudes en la costa del Perú. Nota técnica, Lima, Perú. 1-3. http://www.imarpe.pe/imarpe/archivos/informes/imarpe_comenf_ not_tecni_enfen_09abr12.pdf (accessed 24 July 2015).

Espinoza-Villar JC, Ronchail J, Guyot JL, Cochonneau G, Naziano F, Lavado W, De Oliveira E, Pombosa R, Vauchel P. 2009. Spatio-temporal rainfall variability in the Amazon basin countries (Brasil, Peru, Bolivia, Colombia, and Ecuador). Int. J. Climatol. 29 1574-1594.

Falvey M, Garreaud RD. 2009. Regional cooling in a warming world: recent temperature trends in the southeast Pacific and along the west coast of subtropical South America (1979-2006). J. Geophys. Res. Atmos. 114: D04102.

Garreaud RD. 2009. The Andes climate and weather. Adv. Geosci. 22 3-11.

Garreaud R, Vuille M, Compagnucci R, Marengo J. 2009. Present-day South American climate. Palaeogeogr. Palaeoclimatol. Palaeoecol. 281: $180-195$.

Grimm AM, Barros VR, Doyle ME. 2000. Climate variability in southern South America associated with El Niño and La Niña events. J. Clim. 13: $35-58$

Hare SR, Mantua NJ, Francis RC. 1999. Inverse production regimes: Alaskan and west coast salmon. Fisheries 24: 6-14.

Haylock MR, Peterson TC, Alves LM, Ambrizzi T, Anunciação YMT, Baez J, Barros VR, Berlato MA, Bidegain M, Coronel G, Corradi V, Garcia VJ, Grimm AM, Karoly D, Marengo JA, Marino MB, Moncunill DF, Nechet D, Quintana J, Rebello E, Rusticucci M, Santos JL, Trebejo I, Vincent LA. 2006. Trends in total and extreme South American rainfall in 1960-2000 and links with sea surface temperature. J. Clim. 19: 1490-1512.

Herzog SK, Martínez R, Jørgensen PM, Tiessen H. 2011. Climate Change and Biodiversity in the Tropical Andes. Inter-American Institute for Global Change Research: São José dos Campos, Brazil, 348 pp.

IPCC. 2012. Managing the Risks of Extreme Events and Disasters to Advance Climate Change Adaptation. A Special Report of Working Groups I and II of the Intergovernmental Panel on Climate Change, Field CB, Barros V, TF S, Qin D, Dokken DJ, Ebi KL, Mastrandrea MD, Mach KJ, Plattner G-K, Allen SK, Tignor M, Midgley PM (eds). Cambridge University Press: Cambridge, UK, and New York, NY, $582 \mathrm{pp}$.
Jolliffe I. 2005. Principal Component Analysis. Encyclopedia of Statistics in Behavioral Science. John Wiley \& Sons, Ltd., doi: 10.1002/0470013192.bsa501.

Larkin NK, Harrison DE. 2002. ENSO warm (El Niño) and cold (La Niña) event life cycles: ocean surface anomaly patterns, their symmetries, asymmetries, and implications. J. Clim. 15: 1118-1140.

López-Moreno JI, Fontaneda S, Bazo J, Revuelto J, Azorin-Molina C, Valero-Garcés B, Morán-Tejeda E, Vicente-Serrano SM, Zubieta R, Alejo-Cochachín J. 2014. Recent glacier retreat and climate trends in Cordillera Huaytapallana, Peru. Glob. Planet. Change 112: $1-11$.

Mantua NJ, Hare SJ. 2002. The Pacific Decadal Oscillation. J. Oceanogr. 58: $35-44$.

Mantua NJ, Hare SR, Zhang Y, Wallace JM, Francis RC. 1997. A Pacific interdecadal climate oscillation with impacts on salmon production. Bull. Am. Meteorol. Soc. 78: 1069-1079.

Mestre O, Domonkos P, Picard F, Auer I, Robin S, Lebarbier E, Böhm R, Aguilar E, Guijarro J, Vertachnik G, Klancar M, Dubuisson B, Stepanek P. 2013. HOMER: a homogenization software-methods and applications, Idojaras. Q. J. Hung. Meteorol. Serv. 117: 47-67.

Mora DE, Willems P. 2012. Decadal oscillations in rainfall and air temperature in the Paute River Basin-Southern Andes of Ecuador. Theor. Appl. Climatol. 108: 267-282.

Poveda G, Waylen PR, Pulwarty RS. 2006. Annual and inter-annual variability of the present climate in northern South America and southern Mesoamerica. Palaeogeogr. Palaeoclimatol. Palaeoecol. 234: 3-27.

Rein B. 2007. How do the 1982/83 and 1997/98 El Niños rank in a geological record from Peru? Quat. Int. 161: 56-66.

Richman MB. 1986. Rotation of principal components. J. Climatol. 6(3): 293-335.

Rossel F, Cadier E. 2009. El Nino and prediction of anomalous monthly rainfalls in Ecuador. Hydrol. Processes 23: 3253-3260, doi: 10.1002/hyp.7401.

Rossel F, Le Goulven P, Cadier E. 1999. Areal distribution of the influence of ENSO on the annual rainfall in Ecuador. Rev. Sci. Eau. 12(1).

Seiler C, Hutjes RWA, Kabat P. 2013. Climate variability and trends in Bolivia. J. Appl. Meteorol. Climatol. 52: 130-146.

Skansi MM, Brunet M, Sigró J, Aguilar E, Arevalo-Groening JA, Betancur OJ, Castellón-Geier YR, Correa-Amaya RL, Jácome H, Malheiros-Ramos A, Oria-Rojas C, Pasten AM, Sallons-Mitro S, Villaroel-Jiménez C, Martínez R, Alexander RV, Jones PD. 2013. Warming and wetting signals emerging from analysis of changes in climate extreme indices over South America. Glob. Planet. Change 100: 295-307.

Stocker TF, Qin D, Plattner G-K, Tignor M, Allen SK, Boschung J, Nauels A, Xia Y, Bex V, Midgley PM (eds). 2013. Climate Change 2013: The Physical Science Basis. Contribution of Working Group I to the Fifth Assessment Report of the Intergovernmental Panel on Climate Change. Cambridge University Press: Cambridge, UK

Takahashi K, Montecinos A, Goubanova K, Dewitte B. 2011. ENSO regimes: reinterpreting the canonical and Modoki El Niño. Geophys. Res. Lett. 38: L10704, doi: 10.1029/2011GL047364.

Vicente-Serrano SM, López-Moreno JI, Gimeno L, Nieto R, Morán Tejeda E, Lorenzo-Lacruz J, Beguería S, Azorin Molina C. 2011. A multiscalar global evaluation of the impact of ENSO on droughts. J. Geophys. Res. 116(D20): doi: 10.1029/2011JD016039.

Vuille M, Bradley RS. 2000. Mean annual temperature trends and their vertical structure in the Tropical Andes. Geophys. Res. Lett. 27: 3885-3888.

Vuille M, Bradley RS, Keimig F. 2000. Climate variability in the Andes of Ecuador and its relation to tropical Pacific and Atlantic sea surface temperature anomalies. J. Clim. 13: 2520-2535.

Vuille M, Francou B, Wagnon P, Juen I, Kaser G, Mark BG, Bradley RS. 2008. Climate change and tropical Andean glaciers. Past, present and future. Earth Sci. Rev. 89: 79-96.

WFP. 2014. Food Security, Disasters and Climate Change in the Andean Region. United Nations World Food Programme, WFP.

Yue S, Pilon P, Phinney B, Cavadias G. 2002. The influence of autocorrelation on the ability to detect trend in hydrological series. Hydrol. Processes 16(9): 1807-1829. 